\title{
On the Perspective of Transfer \\ of Omsk Thermal Power Plants \\ to Combustion of Fired Coals
}

\author{
Ainur A. Kuandykova ${ }^{a}$ and Vitaly M. Lebedev ${ }^{b}$ \\ a Public Joint Stock Company «Moscow United Energy Company \\ Moscow, Russian Federation \\ ${ }^{b}$ Omsk State Transport University (OSTU) \\ Omsk, Russian Federation
}

Received 15.10.2020, received in revised form 28.01.2021, accepted 21.02.2021

\begin{abstract}
The existing issues during the combustion of Kazakh coal from the Ekibastuz basin in the Omsk energy system are noted. The environmental problems of coal generation in Omsk are outlined. The possibility of transferring the Omsk coal-fired thermal power plants to the combustion of domestic coals is considered. The options for increasing the efficiency of using solid fossil fuel in the production of electric and thermal energy are given. The existing problem of storing ash and slag wastes obtained by burning high-ash Ekibastuz coals is noted. The transfer of the Omsk CHPPs to the combustion of brown coal from the Kansk-Achinsky deposit, provided that highly effective environmentally friendly technologies are used It is noted that the technology of combustion of fuels in a circulating fluidized bed (CFB) has been industrially developed and implemented in power boilers. The results of operation of the first in Russia CFB boiler of unit No. 9 with a capacity of $330 \mathrm{MW}$ at the Novocherkasskaya SDPP are presented.
\end{abstract}

Keywords: coal-fired power industry, coal-fired thermal power plant, thermal coal, circulating fluidized bed, hazardous emissions, ash and slag waste.

Citation: Kuandykova A.A., Lebedev V.M. On the perspective of transfer of Omsk thermal power plants to combustion of fired coals, J. Sib. Fed. Univ. Eng. \& Technol., 2021, 14(1), 118-129. DOI: 10.17516/1999-494X-0292

(C) Siberian Federal University. All rights reserved

This work is licensed under a Creative Commons Attribution-Non Commercial 4.0 International License (CC BY-NC 4.0).

* Corresponding author E-mail address: vmlebedevomgups@mail.ru 


\title{
О перспективе перевода омских ТЭЦ
}

\section{на сжигание отечественных углей}

\author{
А. А. Куандыкова ${ }^{a}$, В. М. Лебедев ${ }^{\sigma}$ \\ ${ }^{a}$ ПАО «Московская объединенная энергетическая компания» \\ Российская Федераиия, Москва \\ ${ }^{6}$ Омский государственный университет путей сообщения \\ Российская Федерация, Омск
}

\begin{abstract}
Аннотация. Отмечены существующие вопросы при сжигании казахстанского угля Экибастузского бассейна в омской энергосистеме. Обозначены экологические проблемы угольной генерации г. Омска. Рассмотрена возможность перевода омских угольных тепловых электрических станций на сжигание отечественных углей. Приведены варианты повышения эффективности использования твердого органического топлива в сфере производства электрической и тепловой энергии. Отмечена существующая проблема складирования золошлаковых отходов, полученных при сжигании высокозольных экибастузских углей. Рассмотрен перевод омских ТЭЦ на сжигание бурых углей Канско-Ачинского месторождения при условии использования высокоэффективных экологически безопасных технологий. Отмечено, что технология сжигания топлив в циркулирующем кипящем слое (ЦКС) промышленно освоена и реализована в энергетических котлах. Приведены результаты эксплуатации первого в России котла с ЦКС блока № 9 мощностью 330 МВт на Новочеркасской ГРЭС.
\end{abstract}

Ключевые слова: слова: угольная электроэнергетика, угольная тепловая электростанция, энергетический уголь, циркулирующий кипящий слой, вредные выбросы, золошлаковые отходы.

Цитирование: Куандыкова, А.А. О перспективе перевода омских ТЭЦ на сжигание отечественных углей / А.А. Куандыкова, В. М. Лебедев // Журн. Сиб. федер. ун-та. Техника и технологии, 2021, 14(1). C. 118-129. DOI: 10.17516/1999-494X-0292

Угольная промышленность в России обладает значительными разведанными и прогнозными запасами угля. По аналитическим данным Министерства энергетики Российской Федерации, в 2018 г. добыто 439,3 млн т. Основная доля в добыче угля по Российской Федерации принадлежит Сибирскому федеральному округу и составляет 79,6 \% от общего объема.

Для г. Омска, не имеющего собственных источников топливных ресурсов и являющегося энергодефицитным по потреблению электроэнергии, вопрос выбора структуры теплоисточников и топлива с его ценовой конъюнктурой является первостепенным, поскольку лежит в основе экономики крупного промышленного города.

На территории г. Омска функционируют 179 источников тепловой энергии, включая три ТЭЦ и 176 котельных, часть потребителей имеют индивидуальное теплоснабжение (печное отопление, газовые мелкие отопительные котлы). В настоящее время особую значимость в условиях развивающегося рынка приобретают вопросы обоснования потребляемого топлива и организации топливоснабжения, а также конъюнктуры топливообеспечения. В табл. 1 представлены виды потребляемого топлива и объемы его расходов по теплоисточникам за 2018 г. в г. Омске.

Из данных табл. 1 следует, что на котельных независимо от их ведомственной принадлежности доминирующим топливом служит природный газ, его доля в топливном балансе 
Таблица 1. Структура и объем расхода топлива теплоисточниками за 2018 г

Table 1. Structure and volume of fuel consumption by heat sources in 2018

\begin{tabular}{|l|c|c|c|}
\hline \multirow{2}{*}{ Наименование источника теплоты } & \multicolumn{3}{|c|}{ Вид топлива, т у. т. } \\
\cline { 2 - 4 } & природный газ & мазут & уголь \\
\hline ТЭЦ-3 & 1023828 & 2772 & 720867 \\
\hline ТЭЦ-4 & 115959 & 10220 & 1578128 \\
\hline ТЭЦ-5 & 0 & 14980 & 21677 \\
\hline ТЭЦ-2 (в режиме котельной) & 98085 & 281 & 0 \\
\hline Кировская районная котельная & 180499 & 28 & 498 \\
\hline Муниципальные котельные & 127000 & 0 & 1636 \\
\hline Котельные теплоснабжающих организаций & 724000 & 12596 & $2322806(50 \%)$ \\
\hline ИТОГО: & $2269371(49 \%)$ & $40877(1 \%)$ & 280 \\
\hline
\end{tabular}

котельных города составляет более 90 \%. Основным видом топлива на омских ТЭЦ является экибастузский уголь, на его долю приходится до 70 \% общего потребления.

Экибастузский энергетический уголь - проектное топливо омских ТЭЦ-4, ТЭЦ-5, оборудование которых специально спроектировано с учетом особенностей этого вида топлива. Для России чрезмерная зависимость деятельности организации топливно-энергетического комплекса от импорта в области энергетической безопасности - это риск [1]. Фактор принципиальной взаимозависимости развития энергетики и обеспечения национальной безопасности требует особого внимания при рассмотрении вопроса о выборе из всего многообразия углей в перспективе перевода ТЭЦ на его сжигание. Вариантом исключения зависимости омской энергосистемы от суверенного государства Казахстан выступает поэтапный перевод котлов омских ТЭЦ-4 и ТЭЦ-5 на сжигание углей российских месторождений.

Другим важным критерием, характеризующим экибастузский уголь, является высокая зольность (табл. 2). При увеличении зольности угля снижается эффективность пылеугольных

Таблица 2. Физико-химическая характеристика угля Экибастузского бассейна (марка $\mathrm{KCH}$ )

Table 2. Physical and chemical characteristics of coal from the Ekibastuz basin (grade KSN)

\begin{tabular}{|c|c|c|}
\hline Показатели качества & $\begin{array}{c}\text { Пределы } \\
\text { изменения }\end{array}$ & $\begin{array}{l}\text { Среднее } \\
\text { значение }\end{array}$ \\
\hline 1 & 2 & 3 \\
\hline \multicolumn{3}{|l|}{ Технические характеристики } \\
\hline Общая влага в рабочем состоянии топлива,\% & $1,8-4,7$ & 3,4 \\
\hline Влага гигроскопическая,\% & $1,1-2,1$ & 1,6 \\
\hline Зольность в сухом состоянии топлива,\% & $33,5-55,0$ & 45,0 \\
\hline Выход летучих веществ в сухом беззольном состоянии топлива,\% & $26,5-35,6$ & 30,4 \\
\hline Сера общая в сухом состоянии топлива, $\%$ & $0,3-0,6$ & 0,5 \\
\hline Диоксид углерода в сухом состоянии топлива, $\%$ & $0,8-1,9$ & 2,1 \\
\hline
\end{tabular}


Продолжение табл. 2

Continuation of Table. 2

\begin{tabular}{|c|c|c|}
\hline 1 & 2 & 3 \\
\hline \multicolumn{3}{|l|}{ Элементарный состав и теплота сгорания топлива } \\
\hline Сера общая в сухом беззольном состоянии топлива,\% & $0,7-1,1$ & 0,8 \\
\hline Углерод в сухом беззольном состоянии топлива,\% & $76,5-84,1$ & 80,6 \\
\hline Водород в сухом беззольном состоянии топлива,\% & $4,9-5,8$ & 5,3 \\
\hline Азот в сухом беззольном состоянии топлива,\% & $1,3-1,7$ & 1,5 \\
\hline Кислород (по разности) в сухом беззольном состоянии топлива,\% & $8,9-15,5$ & 11,8 \\
\hline Теплота сгорания по бомбе в сухом беззольном состоянии топлива, ккал/кг & $7230-7880$ & 7590 \\
\hline Теплота сгорания низшая в сухом беззольном состоянии топлива, ккал/кг & $6890-7580$ & 7270 \\
\hline Теплота сгорания низшая в рабочем состоянии топлива, ккал/кг & $3090-4740$ & 3850 \\
\hline \multicolumn{3}{|l|}{ Реакционные свойства } \\
\hline Нелетучий остаток & \multicolumn{2}{|c|}{$\begin{array}{l}\text { от слабослипшегося } \\
\text { до спекшегося }\end{array}$} \\
\hline Теплота сгорания летучих веществ, ккал/кг & $5220-7430$ & 6930 \\
\hline $\begin{array}{l}\text { Потеря теплоты сгорания сухой беззольной массы топлива при } \\
\text { окислении, ккал/кг”сут }\end{array}$ & - & 3,3 \\
\hline Коэффициент взрываемости & $0,6-0,9$ & 0,75 \\
\hline \multicolumn{3}{|l|}{ Химический состав минеральной части } \\
\hline $\mathrm{SiO}_{2}, \%$ & $53,9-62,8$ & 61,9 \\
\hline $\mathrm{Al}_{2} \mathrm{O}_{3}, \%$ & $23,0-32,6$ & 27,6 \\
\hline $\mathrm{TiO}_{2}, \%$ & $1,1-1,8$ & 1,3 \\
\hline $\mathrm{Fe}_{2} \mathrm{O}_{3}, \%$ & $0,4-6,4$ & 4,9 \\
\hline $\mathrm{CaO}, \%$ & $0,7-4,5$ & 2,6 \\
\hline $\mathrm{MgO}, \%$ & $0,1-1,3$ & 0,8 \\
\hline $\mathrm{K}_{2} \mathrm{O}, \%$ & $0,4-0,7$ & 0,6 \\
\hline $\mathrm{Na}_{2} \mathrm{O}_{3}, \%$ & $0,2-0,4$ & 0,3 \\
\hline $\mathrm{SO}_{000000000000000000, \%}$ & $0,8-2,9$ & 1,8 \\
\hline $\mathrm{P}_{2} \mathrm{O}_{5}, \%$ & следы-2,2 & 0,7 \\
\hline $\mathrm{MnO}, \%$ & следы- 0,3 & 0,1 \\
\hline \multicolumn{3}{|l|}{ Плавкость золы } \\
\hline $\begin{array}{l}\text { Температура начала деформации золы при ее нагревании } \\
\text { в полувосстановительной среде, }{ }^{\circ} \mathrm{C}\end{array}$ & $1110-1310$ & 1200 \\
\hline $\begin{array}{l}\text { Температура плавления золы при ее нагревании } \\
\text { в полувосстановительной среде, }{ }^{\circ} \mathrm{C}\end{array}$ & $1490->1500$ & 1490 \\
\hline $\begin{array}{l}\text { Температура жидкоплавного состояния золы при ее нагревании } \\
\text { в полувосстановительной среде, }{ }^{\circ} \mathrm{C}\end{array}$ & - & $>1500$ \\
\hline \multicolumn{3}{|l|}{ Показатели шлакующих свойств } \\
\hline Нормированный показатель склонности угля к шлакованию топки & $0,05-0,47$ & 0,28 \\
\hline Температура начала шлакования, ${ }^{\circ} \mathrm{C}$ & $1065-1330$ & 1170 \\
\hline \multicolumn{3}{|l|}{ Физические характеристики } \\
\hline Коэффициент размолоспособности топлива по методу ОР-ВТИ & $1,0-1,3$ & 1,14 \\
\hline Истинная плотность угля, г/см² & $1,72-1,97$ & 1,86 \\
\hline Влага, безопасная по условиям смерзания топлива,\% & $2,7-5,5$ & 4,1 \\
\hline
\end{tabular}


тепловых электрических станций, ухудшаются экологические показатели и возрастает износ оборудования. Вследствие ужесточения в России норм выбросов загрязняющих веществ в окружающую среду существенно обострились негативные стороны энергетического сжигания экибастузского угля. В г. Омске напряженная экологическая ситуация [2], в связи с чем в рамках национального проекта «Экология» разработан региональный проект, который предполагает сократить на 9 \% выбросы от предприятий тепловой генерации. Учитывая масштабы выбросов ТЭЦ, для сохранения окружающей среды приоритетным является снижение выбросов в атмосферный воздух загрязняющих веществ. В связи с этим для возможности решения одной из основных экологических проблем очевидна необходимость перевода омских ТЭЦ на сжигание углей преимущественно отечественных российских месторождений. При этом обоснованное замещение экибастузского угля на отечественные угли на омских ТЭЦ позволит не только повысить энергетическую безопасность страны, но и улучшить экологическую ситуацию в регионе.

Для сжигания каменного угля Экибастузского угольного месторождения создан типоряд уникальных котельных агрегатов: БКЗ-320-140 и БКЗ-420-140, ПК-39 для энергоблоков мощностью 300 МВт, П-57 для энергоблоков 500 МВт, конструирование которых базировалось на таких свойствах угля, как хорошая сыпучесть, взрывобезопасность, несмерзаемость, низкая влажность и умеренная теплота сгорания [3].

В [4] предложен перевод омских ТЭЦ-4, ТЭЦ-5 на кузнецкий уголь марки «СС» Бачатского разреза, близкий по шлакующим свойствам к проектному экибастузскому углю, что потребовало бы минимальной реконструкции котлов БКЗ-420-140-5. Однако не было учтено, что объемы добычи этих углей, даже с учетом перспективы развития разрезов, не смогут обеспечить потребности омских ТЭЦ, в связи с чем проект был остановлен. Позже Сибирским ВТИ были выполнены исследования и расчеты о возможности перевода омских ТЭЦ-4, ТЭЦ-5 на сжигание березовского угля Канско-Ачинского месторождения, запасы которого практически не ограничены. Исследования показали, что угли Канско-Ачинского месторождения в обычном виде не могут сжигаться в котлах БКЗ-420-140-5. Для возможности сжигания березовского угля предложена реконструкция самих котлов с переводом их на работу в режим циркулирующего кипящего слоя (ЦКС), табл. 3.

Важно отметить, что основное оборудование омских ТЭЦ-4, ТЭЦ-5 превысило нормативный срок эксплуатации. Теплоэнергетическое оборудование в результате длительной эксплуатации приобретает физическую усталость и моральное старение, и с каждым годом износ увеличивается. В связи с этим необходима масштабная работа по модернизации, реконструкции и обновлению теплоэнергетического оборудования.

Омская ТЭЦ-4 обеспечивает энергоснабжение крупных промышленных предприятий нефтехимического комплекса, а также незначительную часть жилищно-коммунального сектора двух административных округов г. Омска. Котельное оборудование станции введено в период с 1964 по 1973 г. Для омской ТЭЦ-4 превышен парковый ресурс, который составляет 33 года, и она служит уже более 55 лет. Помимо этого, снижается доля теплофикационной выработки из-за сокращения потребления пара крупными промышленными предприятиями нефтехимического комплекса. В результате это привело к снижению удельной выработки электроэнергии на тепловом потреблении и, как следствие, снижению экономии топлива при 
Таблица 3. Наработка и индивидуальный ресурс котлов омских ТЭЦ-4, ТЭЦ-5 по состоянию на 01.01.2018

Table 3. Operating time and individual resource of boilers at Omsk CHPP-4, CHPP-5 as of 01.01.2018

\begin{tabular}{|c|c|c|c|c|c|c|}
\hline Ст.№ & $\begin{array}{c}\text { Тип (марка) } \\
\text { оборудования }\end{array}$ & $\begin{array}{c}\text { Год ввода } \\
\text { в эксплуата- } \\
\text { цию }\end{array}$ & $\begin{array}{c}\text { Количество } \\
\text { пусков с начала } \\
\text { эксплуатации, шт. }\end{array}$ & $\begin{array}{c}\text { Наработка } \\
\text { с начала } \\
\text { эксплуатации, ч }\end{array}$ & $\begin{array}{c}\text { Расчетный } \\
\text { парковый } \\
\text { ресурс, ч }\end{array}$ & $\begin{array}{c}\text { Остаточный } \\
\text { ресурс, ч }\end{array}$ \\
\hline \multicolumn{7}{|c|}{ Омская ТЭЦ-4 } \\
\hline 4 & БКЗ-320-140 & 1968 & 617 & 256632 & 300000 & 43368 \\
\hline 7 & БКЗ-420-140 & 1972 & 637 & 258844 & 300000 & 41156 \\
\hline 8 & БК3-420-140 & 1973 & 669 & 241347 & 300000 & 58653 \\
\hline 9 & БКЗ-420-140 & 1974 & 622 & 219184 & 300000 & 80816 \\
\hline 11 & БКЗ-420-140 & 1979 & 536 & 162653 & 300000 & 137347 \\
\hline 12 & БК3-420-140 & 1982 & 512 & 172106 & 300000 & 127894 \\
\hline \multicolumn{7}{|c|}{ Омская ТЭЦ-5 } \\
\hline 1 & БКЗ-420-140-5 & 1980 & 388 & 206518 & 264000 & 57482 \\
\hline 2 & БК3-420-140-5 & 1981 & 349 & 201116 & 264000 & 62884 \\
\hline 3 & БК3-420-140-5 & 1982 & 395 & 188479 & 264000 & 75521 \\
\hline 4 & БКЗ-420-140-5 & 1983 & 304 & 185415 & 264000 & 78585 \\
\hline 5 & БК3-420-140-5 & 1984 & 351 & 167895 & 264000 & 96105 \\
\hline 6 & БКЗ-420-140-5 & 1985 & 329 & 161273 & 264000 & 102727 \\
\hline 7 & БК3-420-140-5 & 1986 & 320 & 146277 & 264000 & 117723 \\
\hline 8 & БКЗ-420-140-5 & 1988 & 301 & 141236 & 264000 & 122764 \\
\hline 9 & БКЗ-420-140-5 & 1989 & 265 & 133577 & 264000 & 130423 \\
\hline
\end{tabular}

Таблица 4. Отпуск электрической энергии, удельные расходы топлива на отпуск единицы продукции за 2018 г.

Table 4. Supply of electrical energy, specific fuel consumption for supply of a unit of production for 2018

\begin{tabular}{|l|l|l|}
\hline \multicolumn{1}{|c|}{ Показатель } & \multicolumn{1}{|c|}{ ТЭЦ-4 } & \multicolumn{1}{c|}{ ТЭЦ-5 } \\
\hline Общий отпуск электрической энергии, млн кВт'ч, в том числе: & 1274,76 & 2728,67 \\
\hline отпуск электрической энергии в теплофикационном режиме, млн кВт'ч & 618,06 & 1947,54 \\
\hline отпуск электрической энергии в теплофикационном режиме, процент & 41,3 & 60,8 \\
\hline Удельный расход условного топлива на отпуск электрической энергии, г/ кВт'ч & 414,0 & 351,0 \\
\hline Удельный расход условного топлива на отпуск тепловой энергии, кг/ ГДж & 38,76 & 34,04 \\
\hline
\end{tabular}

комбинированной выработке энергии (табл. 4). Загрузка омской ТЭЦ-4 определяется объемом отпуска тепловой энергии и потребностью в электрической энергии региона. В связи с вводом новых источников тепла на крупных промышленных предприятиях, которые составляют основу теплопотребления, в том числе на объектах нефтехимического комплекса (например, АО «Газпромнефть» - 1323 ГДж/ч), омская ТЭЦ-4 была вынуждена вывести из эксплуатации турбоагрегат Р-100-130 № 8 и два котла БК3-320-140 № 5, 10. С 2004 г. начато сжигание попутного газа на одном котле БКЗ-420-140 № 7, который был переведен для работы на данный вид топлива.

$$
-123-
$$


Основным топливом омской ТЭЦ-5 является каменный уголь Экибастузского месторождения марки КСНр-300; резервного топлива, кроме растопочного, нет. ТЭЦ-5 самая мощная станция энергосистемы г. Омска. Установленная электрическая мощность - 735 МВт, установленная тепловая мощность - 7381,33 ГДж/ч. Электроэнергетическая часть станции введена в эксплуатацию в октябре 1980 г. Омская ТЭЦ-5 отработала нормативный срок эксплуатации, который составляет 33 года, и она функционирует уже более 38 лет.

Высокая зольность экибастузского угля вызывает большой выход золошлаковых отходов (ЗШО) на золоотвал. В Омской области практически отсутствует рынок ЗШО. Ежегодно на золоотвалы ТЭЦ отправляется более 2,0 млн т золы, что требует значительных затрат на их строительство и отвод дополнительных земель. В случае, когда ёмкость золошлакоотвала исчерпывается, энергокомпании проводят работы по наращиванию дамбы, увеличивая земельные площади под ЗШО. По экспертной оценке, стоимость строительства нового золошлакоотвала может составлять от 2,0 до 4,0 млрд руб. [5]. Повышает эксплуатационные расходы расположение золоотвала омской ТЭЦ-5 на ощутимом удалении от станции. Наряду с этим, высокая зольность экибастузского угля и территориальное положение станции относительно розы ветров увеличивают затраты как на природоохранные мероприятия, так и на эксплуатацию и ремонт электрофильтров. Для уменьшения остаточной зольности на котельной установке № 9 омской ТЭЦ-5 внедрен в эксплуатацию оригинальный рукавный фильтр. Однако, согласно [2], данное мероприятие не оказывалось достаточным для обеспечения природоохранных мероприятий со стороны тепловой генерации и улучшения экологической обстановки в регионе. Рукавные фильтры при сжигании многозольных углей не пригодны.

Ведущее положение по эффективности российской угледобычи остается за Кузнецким и Канско-Ачинским бассейнами, обладающими значительными запасами углей различного марочного состава. Особенность выбора альтернативных экибастузскому углей состоит в том, что все известные угли России имеют менее тугоплавкую золу (более шлакующую) и, соответственно, котлы для них лимитированы другими параметрами конструирования топочного устройства. Поэтому при замещении экибастузского угля первоочередным вопросом является анализ температурного уровня и условий шлакования экранированных стен топки котельного агрегата. Топочная камера котла БКЗ-420-140 с твердым шлакоудалением имеет габариты по высоте 27,3 м, по ширине 15,744 м и по глубине 9,024 м, полностью экранирована трубами диаметром 60 мм с толщиной стенки 5,5 мм, расположенными с шагом 64 мм. В качестве замещающих проектное топливо рассматриваются угли: каменный Кузнецкого бассейна и бурый Канско-Ачинского бассейна. При выборе альтернативных рассматриваемым в [4] месторождений Кузнецкого бассейна дополнительно во внимание были приняты разведанные и предварительно оцененные запасы углей. Непроектное топливо зачастую не способно заместить проектное в своем исходном виде, поэтому для его эффективного и экологичного использования [6] необходимы в первую очередь предварительные исследования теплотехнических свойств углей (табл. 5).

По данным табл. 5, замещение экибастузского угля на сжигание каменных углей Кузнецкого бассейна по зольности уступает бурому Канско-Ачинского бассейна почти в три раза (22 к 7 \% соответственно). Каменные угли Талдинского разреза наиболее близки по склонности к шлакованию и загрязнению золой поверхностей нагрева котлов к экибастузскому углю. Ис- 
Таблица 5. Теплотехнические характеристики углей

Table 5. Thermal characteristics of coals

\begin{tabular}{|c|c|c|c|c|}
\hline \multirow[b]{2}{*}{ Показатели качества } & \multicolumn{4}{|c|}{ Среднее значение } \\
\hline & $\begin{array}{c}\text { Экибастуз- } \\
\text { ского } \\
\text { бассейна } \\
\text { (марка КСН) }\end{array}$ & $\begin{array}{l}\text { Талдинского } \\
\text { разреза } \\
\text { (марка ДГ) }\end{array}$ & $\begin{array}{l}\text { Камышанско- } \\
\text { го разреза } \\
\text { (марка ТРОК) }\end{array}$ & $\begin{array}{l}\text { Березовского } \\
\text { месторожде- } \\
\text { ния (2Б) }\end{array}$ \\
\hline $\begin{array}{l}\text { Общая влага в рабочем состоянии } \\
\text { топлива, } \%\end{array}$ & 3,4 & 8,6 & 12,8 & 33,0 \\
\hline Влага гигроскопическая,\% & 1,6 & 3,9 & 5,5 & 12,2 \\
\hline $\begin{array}{l}\text { Зольность в сухом состоянии топли- } \\
\text { ва,\% }\end{array}$ & 45,0 & 16 & 22,0 & 7,0 \\
\hline $\begin{array}{l}\text { Выход летучих веществ в сухом без- } \\
\text { зольном состоянии топлива,\% }\end{array}$ & 30,4 & 37,1 & 14,5 & 47,7 \\
\hline $\begin{array}{l}\text { Сера общая в сухом состоянии топли- } \\
\text { ва,\% }\end{array}$ & 0,5 & 0,5 & 0,7 & 0,3 \\
\hline $\begin{array}{l}\text { Теплота сгорания низшая в рабочем } \\
\text { состоянии топлива, ккал/кг }\end{array}$ & 3850 & 5750 & 5730 & 3730 \\
\hline $\begin{array}{l}\text { Температура начала деформации золы } \\
\text { при ее нагревании в полувосстанови- } \\
\text { тельной среде, }{ }^{\circ} \mathrm{C}\end{array}$ & 1200 & 1280 & 1280 & 1260 \\
\hline $\begin{array}{l}\text { Температура плавления золы при ее } \\
\text { нагревании в полувосстановительной } \\
\text { среде, }{ }^{\circ} \mathrm{C}\end{array}$ & 1490 & 1480 & 1370 & 1310 \\
\hline $\begin{array}{l}\text { Температура жидкоплавного состоя- } \\
\text { ния золы при ее нагревании в полувос- } \\
\text { становительной среде, }{ }^{\circ} \mathrm{C}\end{array}$ & $>1500$ & $>1500$ & 1410 & 1340 \\
\hline $\begin{array}{l}\text { Нормированный показатель склонно- } \\
\text { сти угля к шлакованию топки }\end{array}$ & 0,28 & 0,31 & 0,6 & 0,84 \\
\hline Температура начала шлакования, ${ }^{\circ} \mathrm{C}$ & 1170 & 1160 & 1050 & 1020 \\
\hline
\end{tabular}

следования возможности сжигания углей Кузнецкого месторождения (Черниговского и Бочатского разрезов) на установленном оборудовании омской ТЭЦ-5 позволят избежать значительных экономических затрат на реконструкцию оборудования [7]. При этом для надежной работы электростанций при использовании кузнецких углей необходимо осуществить реконструкцию топливно-транспортного хозяйства и системы пылеприготовления для устранения трудностей при прохождении топлива по тракту топливоподачи и обеспечения взрывобезопасной эксплуатации. Применение низкозольных бурых углей Канско-Ачинского бассейна при их сжигании в топочных устройствах открытого типа с сухим шлакоудалением вызывает ряд трудностей, главными из которых являются образование связных отложений на конвективных поверхностях нагрева, находящихся в зоне температур газов $800-1000{ }^{\circ} \mathrm{C}$, и шлакование радиационных поверхностей нагрева, расположенных в топочной камере. Существующая практика сжигания углей Канско-Ачинского бассейна в топочных устройствах различных конструкций показала, что процесс шлакования может быть полностью ликвидирован или интенсивность протекания этого процесса значительно уменьшиться при сжигании углей в высокофорсированных топочных устройствах с жидким шлакоудалением при организации высокотемпературного процесса

$$
-125-
$$


горения и высокотемпературной обработке всей массы золы в процессе сжигания. Учитывая это, реконструкция котлоагрегатов омской ТЭЦ-5 на сжигание бурых углей Канско-Ачинского месторождения требует значительных финансовых затрат.

Наряду с этим, при разработке экологических требований к котельным установкам для трех основных загрязнителей атмосферного воздуха (золовые частицы, $\mathrm{SO}_{2}, \mathrm{NO}_{\mathbf{x}}$ ) в первую очередь всегда учитывали мощность котельного агрегата и срок службы оборудования, причем если парковый ресурс котла близок к завершению, то обосновать большие затраты на его реконструкцию вряд ли удастся, а если котел только собирается сооружаться, то экологические требования должны учитывать не только существующие требования, но и ожидаемое ужесточение норм по вопросам загрязняющих веществ [8]. Эксплуатация котлов омских ТЭЦ-4, ТЭЦ-5, спроектированных 40-50 лет назад, стремится к сроку достижения расчетного паркового ресурса. Они не соответствуют не только перспективным, но и зачастую существующим нормам на вредные выбросы. Масштаб возникающих вследствие этого экологических проблем требует неотложного технического перевооружения ТЭЦ на основе прогрессивных решений с использованием наилучших доступных технологий (НТД). Для создания экологически чистой тепловой энергетики в регионе предлагается поэтапное внедрение на омской ТЭЦ-5 котлов с циркулирующим кипящим слоем, обеспечивающих перспективные нормативы по выбросам золы, оксидов азота и серы при сжигании различных углей.

В настоящее время технология сжигания топлив в ЦКС является общепризнанной промышленной технологией, реализованной на многих иностранных объектах. Первый энергетический котел с ЦКС пущен в Финляндии в 1979 г. Развитие технологий кипящего слоя направлено, с одной стороны, на обеспечение эффективного сжигания низкокачественного топлива в широком диапазоне изменения нагрузки котлов без использования для подсветки газообразного и жидкого топлива, а с другой - на максимальное сокращение выбросов оксидов серы, азота и летучей золы. Преимуществами технологии являются высокие экологические характеристики при низких требованиях к качеству сжигаемого топлива. В России сооружен первый котел с ЦКС блока № 9 мощностью 330 МВт на Новочеркасской ГРЭС с использованием импортного оборудования. В конце января 2016 г. блок впервые вошел в сеть. Опыт сооружения и пуска этого блока создал условия для широкого внедрения технологии ЦКС в России [9]. Проект осуществлялся в соответствии с распоряжением Правительства РФ № 1334-р от 11 августа 2010 г. «Об утверждении перечня генерирующих объектов, с использованием которых будет осуществляться поставка мощности по договорам о предоставлении мощности». Ввод энергоблока позволил увеличить спрос на низкореакционные угли Донецкого бассейна. Удельный расход условного топлива нового энергоблока № 9 на Новочеркасской ГРЭС составил 323,9 г/кВт·ч. Выбросы вредных веществ блока № 9 с дымовыми газами значительно ниже существующих нормативных и чем выбросы любого из настоящих угольных энергоблоков в России. Уровень выброса оксида серы не более 400 мг/куб. м при нормативе в РФ 700 мг/куб. м, оксидов азота не более 300 мг/куб. м при нормативе в РФ 570 г/куб. м.

Технический проект по использованию бурых углей Канско-Ачинского месторождения со сжиганием в топках с циркулирующим кипящим слоем (ЦКС) был разработан конструкторами Барнаульского котельного завода для омской ТЭЦ-6 в конце 1990-х гг. В 1980-х гг. началось строительство омской ТЭЦ-6, которое прекратилось из-за снижения финансирования 
по строительству тепловых электростанций. Одновременно Омская область более 30 \% потребляемой электроэнергии закупает из других регионов (электростанции Сибири и Северного Казахстана), новая электростанция решила бы проблему дефицита своих энергетических мощностей. Перевод крупной Кировской районной котельной г. Омска, тепловая мощность которой составляет 2491,15 ГДж/ч, на комбинированный способ производства энергии омской ТЭЦ-6 позволил бы увеличить прибыль предприятия за счет повышения экономичности работы и увеличения отпуска электроэнергии, а также появилась бы возможность проведения реконструкции существующего основного энергетического оборудования омской ТЭЦ-5. Строительство омской ТЭЦ-5 до проектной мощности 880/ 1070 МВт не закончено. ТЭЦ-5 является базовым объектом теплоснабжения г. Омска, обеспечивая теплом до 40-45 \%, и требования к надежности ее работы постоянно возрастают. Учитывая значение ТЭЦ-5, предлагается ее развитие путем строительства второго ввода топливоподачи и дальнейшее расширение станции за счет ввода котлоагрегатов № 10, 11, 12 типа БКЗ-420-140-5 со сжиганием бурых углей Канско-Ачинского месторождения в топках с циркулирующим кипящим слоем и турбоагрегата № 6 электрической мощностью 185/220 МВт, тепловой 1172,3 ГДж/ч. Это позволит не только начать переход на использование дешевых российских углей, но и резко улучшить экологическую обстановку, не требуя увеличения площади золоотвала. Сама зола бурых углей КанскоАчинского месторождения, имея не менее 16 \% вяжущего оксида кальция, может полностью использоваться для строительных нужд [10]. Для реализации данного предложения, в первую очередь, необходима разработка проектной документации, в которой будут определены габаритные размеры модернизируемых котлов БКЗ-420-140-5 с ЦКС. Освоение бурых углей Канско-Ачинского месторождения в топках с ЦКС на котлах № 10, 11, 12 позволит начать поэтапную реконструкцию котлов БКЗ-420-140-5 первой очереди омской ТЭЦ-5.

В пользу перспективы сжигания бурых углей Канско-Ачинского месторождения в топках с ЦКС свидетельствует возможность улучшения не только экономических показателей, но и, что особенно важно, резкое снижение вредных выбросов оксидов серы и азота в атмосферу. Помимо этого, угли Канско-Ачинского месторождения имеют малую зольность, что практически исключает наличие золоотвала.

Ведущими исследовательскими организациями России на основе методики расчета котлов с ЦКС разработана компьютерная программа расчета и применена при обосновании технических решений по котлам с ЦКС для технического перевооружения ТЭС и ТЭЦ. Определены условия наиболее эффективного применения этой технологии сжигания для технического перевооружения ТЭС России, касающиеся качества топлива, требований к вредным выбросам и возможности сжигания различных топлив в одном и том же котле (диверсификация поставок топлива).

В мире широко используются и развиваются угольные блоки с котлами, сжигающими топливо в ЦКС. Только в Китае их насчитывается около трех тысяч единиц. В 2013 г. на ТЭС Sichuan Baima введен в эксплуатацию первый в мире энергоблок мощностью 600 МВт с котлом с ЦКС и повышенными параметрами пара $\left(4,8 \mathrm{MПа} \mathrm{и} 570{ }^{\circ} \mathrm{C}\right)$ с удельным расходом условного топлива 299,9 г/кВт·ч [11].

Как известно, теплоэнергетику России сегодня нельзя считать экологически чистой, в особенности серьезные проблемы наблюдаются на ТЭС, сжигающих уголь. В настоящее время

$$
-127 \text { - }
$$


на российских угольных ТЭС количество действующих установок сероочистки дымовых газов ничтожно мало. Мировой опыт показывает, что развитие угольных объектов экономически оправданно при условии использования высокоэффективных экологически безопасных технологий.

В России теплотехническими исследованиями в данном направлении занимается ОАО «Всероссийский теплотехнический институт». В качестве полноценного варианта им разработано использование котла с ЦКС, обеспечивающего большую свободу в выборе топлива и меньшие концентрации вредных соединений в уходящих газах [12]. Разработки и исследования перспективных угольных ТЭЦ России подтвердили целесообразность широкого использования котлов с ЦКС, несомненным достоинством которых являются низкие выбросы оксидов азота и серы, достигаемые без использования специальных средств очистки дымовых газов, и большая топливная гибкость. Котлы с топками с ЦКС всеядны.

Топливно-энергетический комплекс г. Омска характеризуется значительным потенциалом в области оптимизации и повышения эффективности производственных процессов потребления энергетических ресурсов при обновлении технологической базы. Переход на сжигание отечественных углей в котлах с ЦКС на омских ТЭЦ-4, ТЭЦ-5 позволит обеспечить оптимальные сочетания энергетических, экологических и экономических показателей.

\section{Список литературы}

[1] Указ Президента Российской Федерации от 13 мая 2019 г. N216 «Об утверждении Доктрины энергетической безопасности Российской Федерации» [Decree of the President of the Russian Federation of May 13, 2019 N216 «On approval of the Doctrine of energy security of the Russian Federation» (in Russian)].

[2] Указ Президента Российской Федерации от 7 мая 2018 г. № 204 «О национальных целях и стратегических задачах развития Российской Федерации на период до 2024 года» [Decree of the President of the Russian Federation of May 7, 2018 No. 204 «On national goals and strategic objectives for the development of the Russian Federation for the period until 2024» (in Russian)].

[3] Гаврилов А.Ф., Гаврилов Е.И. Экологические аспекты замещения экибастузского угля кузнецкими углями на ТЭС России. Теплоэнергетика. 2004. № 12. $23-28$ [Gavrilov A.F., Gavrilov E. I. Environmental aspects of replacing Ekibastuz coal with Kuznetsk coal at TPPs in Russia. Teploenergetika, 2004, no. 12, 23-28.(in Russian)].

[4] Щадов В.В., Гаврилов Е.И., Гаврилов А.Ф., Толчинский Е.Н., Вербовецкий Э. Х., Левит Г.Т., Бранчугов В.К., Жигуленкова А.И. Замещение экибастузкого угля кузнецким на электростанциях России. Теплоэнергетика. 2001. № 7. 23-29 [Shchadov V.V., Gavrilov E.I., Gavrilov A.F., Tolchinsky E.N., Verbovetsky E. Kh., Levit G.T., Branchugov V.K., Zhigulenkova A.I. Replacement of Ekibastuz coal with Kuznetsk coal at power plants in Russia. Teploenergetika, 2001, no. 7, 23-29. (in Russian)].

[5] Целыковский Ю. К. Складирование и использование золошлаковых отходов угольных ТЭС. Электрические станции. 2016. № 7. 38-43 [Tselykovsky Yu. K. Warehousing and use of ash and slag waste from coal TPPs. Electric stations, 2016, no. 7, 38-43. (in Russian)].

[6] Гиль А.В., Старченко А.В., Заворин А. С. Применение численного моделирования топочных прочессов для практики перевода котлов на непроектное топливо: монография. Томск: 
STT, 2011. 181 c. [Gil A.V., Starchenko A.V., Zavorin A.S. Application of numerical modeling of furnace processes for the practice of converting boilers to non-design fuel: monograph. Tomsk: STT, 2011.181 p. (in Russian)]

[7] Гаак В. К. Пути реконструкиии оборудования промышленной ТЭЦ при переводе на сжигание других видов топлива на примере омской ТЭЦ-5. Дисс. ... канд. техн. наук. Омск, 1999. 158 c. [Gaak V.K. Ways of reconstruction of the equipment of an industrial CHPP when switching to combustion of other types of fuel: On the example of Omsk CHPP-5. Dis. ... of cand. of tech. sci. Omsk, 1999. 158 p. (in Russian)]

[8] Котлер В.Р., Баторшин В.А. Выбор и обоснование допустимых удельных выбросов оксидов азота на угольных котлах. Электрические станции. 2016. № 12. 28-32 [Kotler V.R., Batorshin V.A. Selection and substantiation of permissible specific emissions of nitrogen oxides from coal-fired boilers. Electric stations, 2016, no. 12. 28-32. (in Russian)].

[9] Рябов Г.А. Развитие технологии сжигания топлив в циркулирующем кипящем слое: исследования ОАО «ВТИ» в обоснование её использования в России. Электрические станции. 2016, 6. 15-21 [Ryabov G. A. Development of the technology of combustion of fuels in a circulating fluidized bed: research of JSC VTI to substantiate its use in Russia, Electric Power Plants, 2016, no. 6, 15-21. (in Russian)].

[10] Лебедев В.М., Гаак В.К. Перспективы развития омской ТЭЦ-5. Межвуз.тематический сб. науч. тр. 2016. 9-12 [Lebedev VM, Gaak VK Prospects for the development of the Omsk CHPP-5. Interuniversity subject collection of scientific papers. 2016. 9-12. (in Russian)].

[11] Тугов А.Н. Развитие электроэнергетики в Китае. Энергохозяйство за рубежом. 2016. № 4. 7-14 [Tugov A. N. The development of the electric power industry in China. Energy industry abroad, 2016, no. 4, 7-14. (in Russian)].

[12] Ольховский Г.Г., Реутов Б.Ф., Тумановский А.Г. К 95-летию ВТИ. Электрические станичии. 2016. № 6. 2-14 [Olkhovsky G. G., Reutov B. F., Tumanovsky A. G. To the 95th anniversary of VTI. Electric stations, 2016, no. 6, 2-14. (in Russian)]. 